\title{
Pengenalan Huruf Pada Citra Digital Menggunakan Algoritma Template Matching
}

\author{
Munjiat Setiani Asih, ST, M.Kom \\ Jurusan Teknik Informatika Sekolah Tinggi Teknik Harapan Medan \\ J1. H.M. Joni No. 70C Medan 20152 Indonesia \\ E-mail :munjiat.stth@gmail.com
}

\begin{abstract}
Abstrak
Template matching merupakan salah satu metode yang digunakan untuk mengenali pola tertentu didalam citra digital. Manusia dapat mengenali huruf dengan mudah, baik dalam bentuk gambar, dokumen, ataupun bentuk lainnya yang sulit untuk digambarkan. Berbeda halnya dengan komputer, komputer harus memiliki algoritma tertentu untuk mengenali objek yang ada di alam ini. Misalnya komputer akan diajarkan untuk mengenali huruf didalam gambar, maka pengguna harus mengajarkan komputer pola-pola tertentu untuk dijadikan sebagai basis pengetahuan komputer tersebut. Algoritma template matching merupakan salah satu algoritma yang dapat dimanfaatkan untuk mengenali pola huruf didalam citra digital. Pemanfaatan metode ini dapat digunakan pada aplikasi OCR (Optical Character Recognition) untuk mengenali huruf dalam dokumen yang berbentuk citra digital. OCR merupakan salah satu contoh aplikasi yang dapat mengenali karakter didalam citra digital. Algoritma template matching akan membandingkan data masukan dengan data yang digunakan untuk pelatihan yang sudah dikenali sebelumnya.

(Kata Kunci: Template Matching, Pengenalan Pola, Citra Digital, Huruf, Optical Character Recognition)
\end{abstract}

\section{Pendahuluan}

Perkembangan teknologi yang berkembang pesat sudah merambah kedalam bidang sistem cerdas. Salah satu penerapan sistem cerdas ini yaitu pengenalan pola huruf pada citra digital yang dapat dikenali oleh komputer. Dengan adanya pengenalan huruf dapat membantu pengguna untuk mengenali huruf, terutama dibidang pendidikan yang berkaitan dengan pengenalan dasar huruf.

Berbeda dengan manusia yang memiliki kecerdasan alami, komputer harus memiliki algoritma tertentu yang digunakan untuk membentuk kecerdasan yang akan dimilikinya untuk mengenali huruf didalam citra digital.

Algoritma yang dapat digunakan yaitu algoritma template matching, algoritma ini memanfaatkan kemiripan template untuk memeriksa kemiripan antara gambar satu dengan gambar yang lainnya. Semakin dekat nilai piksel antara gambar tersebut maka gambar tersebut akan semakin mirip dengan gambar masukan. Algoritma template matching merupakan algoritma yang sangat mudah untuk diterapkan, tetapi memiliki kelemahan. Salah satu kelemahan algoritma ini yaitu membutuhkan tempat penyimpanan yang besar untuk menampung citra training, semakin banyak citra training yang dimiliki sistem maka semakin baik pula aplikasi mengenali huruf yang ada pada citra digital masukan.

\section{Pengenalan Pola}

Pola dapat diartikan sebagai model atau contoh. Secara umum pola dapat didefinisikan sebagai hubungan data analog ataupun digital, kejadian atau konsep yang dapat dibedakan. Bentuk wajah, sidik jari, mata, nada sebait musik, lintasan yang dibuat secara zig-zag, semuanya merupakan contoh dari pola-pola yang berlainan.

Secara umum pengenalan pola dapat dibedakan menjadi dua yaitu pengenalan pola langsung (konkret) dan tidak langsung (konseptual). Pengenalan pola langsung mencakup pengenalan visual dan aural spasial (krakter, gambar, sidik jari, tanda tangan, dsb) dan temporal (gelombang, ucapan, ECG, dsb) dimana seseorang membutuhkan sensor. 


\section{OCR (Optical Character Recognition)}

OCR (Optical Character Recognition) adalah sebuah aplikasi komputer yang digunakan untuk mengenali/mengidentifikasi citra huruf untuk dikonversikan kebentuk file tulisan. Sistem pengenalan huruf ini dapat meningkatkan kecerdasan yang dimiliki oleh komputer. Sistem pengenalan huruf yang cerdas sangat dibutuhkan saat sekarang ini dalam bidang-bidang tertentu yang membutuhkan pembacaan karakter dalam citra, misalnya koleksi pustaka digital seperti google book, koleksi sastra kuno digital dan lain sebagainya. Secara umum proses OCR dapat dilihat pada gambar berikut.

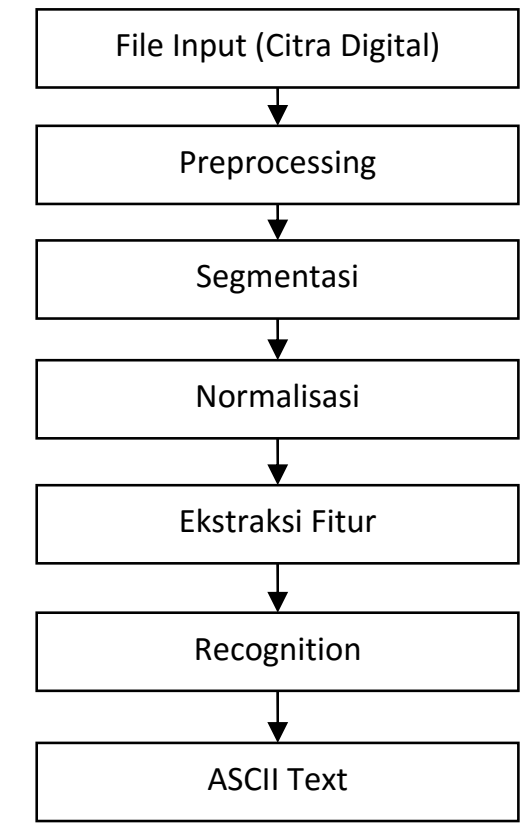

Gambar 1. Proses OCR Secara Umum

\section{Template Matching}

Template matching merupakan algoritma yang banyak digunakan untuk mengenali pola, algoritma ini banyak dipilih karena penerapannya yang sangat sederhana dan mudah. Citra masukan akan dibandingkan dengan citra yang terdapat didalam basis data. Citra masukan dijadikan sebagai pusat dari bagian citra digital yang akan dibandingkan dan dihitung seberapa banyak titik yang paling sesuai dengan template. Langkah ini diulangi terus menerus sampai seluruh citra selesai dibandingkan dengan citra masukan.

Nilai kesesuaian titik yang paling mendekati atau error minimum yang paling kecil antara citra masukan dan citra yang terdapat dalam basis data menandakan bahwa citra tersebut merupakan citra yang paling sesuai dengan citra masukan.

Tingkat kesesuaian citra masukan dengan citra yang terdapat didalam basis data dapat dihitung berdasarkan nilai error terkecil dengan menggunakan persamaan berikut.

Min $e=\sum(I x, y-T x, y)^{2}$

I adalah pola piksel masukan yang akan dibandingkan. $\mathrm{T}$ adalah pola piksel citra template (citra yang terdapat dalam basis data). Template dengan nilai error paling kecil adalah template yang paling sesuai dengan citra masukan yang dibandingkan. 


\section{Analisis Template Matching}

Untuk mengenali huruf dalam citra digital, terdapat langkah-langkah yang harus dilakukan antara lain:

1. Citra masukan harus dirubah terlebih dahulu menjadi citra biner agar memudahkan proses pengenalan huruf

2. Lakukan pemisahan huruf didalam citra

3. Ubah resolusi citra huruf/sesuaikan dengan citra didalam basis data

4. Lakukan proses pengenalan huruf dengan manggunakan rumus template matching

Untuk lebih jelasnya lihat contoh berikut:

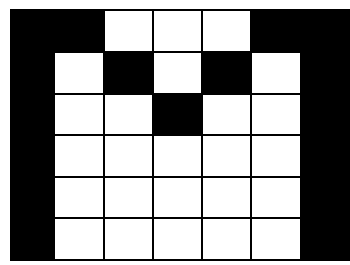

Gambar 2. Citra Input

Secara kasat mata manusia dapat mengenali citra input tersebut merupakan huruf "M", tetapi komputer harus melakukan pengenalan huruf tersebut dengan algoritma template matching. Setelah diketahui citra input selanjutnya diperoleh citra yang terdapat didalam basis data sebagai berikut:

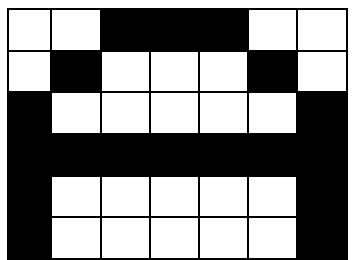

(a)

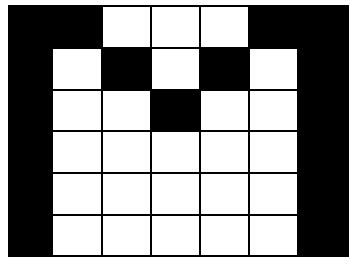

(c)

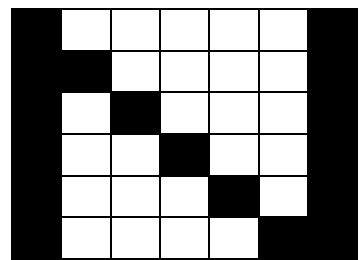

(b)

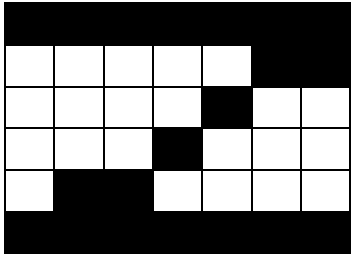

(d)

Gambar 3 (a) Huruf A (b) Huruf N (c) Huruf M (d) Huruf Z

Dari gambar 3, nilai piksel dari citra diambil dan dapat dilihat pada tabel berikut.

Tabel 1. Nilai Citra Yang Terdapat Dalam Basis Data

\begin{tabular}{|c|c|c|}
\hline Karakter & \multicolumn{4}{|c|}{ Nilai } \\
\hline $\mathrm{A}$ & 11000011101110101111100 \\
& 000000001111100111110 \\
\hline $\mathrm{N}$ & 01111100001111001011100 \\
& 110110001110100111100 \\
\hline $\mathrm{M}$ & 00111000101010011001100 \\
& 111111001111100111110 \\
\hline $\mathrm{Z}$ & 000000000111110011110111 \\
& 1100111100111100000000 \\
\hline
\end{tabular}


Sedangkan untuk citra masukan dapat dilihat pada tabel berikut.

Tabel 2. Nila Citra masukan

\begin{tabular}{|c|l|lllllllllllllllllllll|}
\hline Karakter & \multicolumn{1}{|c|}{ Nilai } \\
\hline $\mathrm{M}$ & 0 & 0 & 1 & 1 & 1 & 0 & 0 & 0 & 1 & 0 & 1 & 0 & 1 & 0 & 0 & 1 & 1 & 0 & 1 & 1 & 0 & 0 \\
& 1 & 1 & 1 & 1 & 1 & 0 & 0 & 1 & 1 & 1 & 1 & 1 & 0 & 0 & 1 & 1 & 1 & 1 & 1 & 0 & \\
\hline
\end{tabular}

Hasil dari perhitungan error menggunakan persamaan (1) dapat dilihat pada tabel 3 berikut.

Tabel 3. Hitungan Nilai Error

\begin{tabular}{|c|c|}
\hline Karakter & Nilai \\
\hline $\mathrm{A}$ & $\begin{array}{l}(1-0)^{2}+(1-0)^{2}+(0-1)^{2}+(0-1)^{2}+ \\
(0-1)^{2}+(1-0)^{2}+(1-0)^{2}+(1-0)^{2}+ \\
(0-1)^{2}+(1-0)^{2}+(1-1)^{2}+(1-0)^{2}+ \\
(0-1)^{2}+(1-0)^{2}+(0-0)^{2}+(1-1)^{2}+ \\
(1-1)^{2}+(1-0)^{2}+(1-1)^{2}+(1-1)^{2}+ \\
(0-0)^{2}+(0-0)^{2}+(0-1)^{2}+(0-1)^{2}+ \\
(0-1)^{2}+(0-1)^{2}+(0-1)^{2}+(0-0)^{2}+ \\
(0-0)^{2}+(1-1)^{2}+(1-1)^{2}+(1-1)^{2}+ \\
(1-1)^{2}+(1-1)^{2}+(0-0)^{2}+(0-0)^{2}+ \\
(1-1)^{2}+(1-1)^{2}+(1-1)^{2}+(1-1)^{2}+ \\
(1-1)^{2}+(0-0)^{2}=19\end{array}$ \\
\hline $\mathrm{N}$ & $\begin{array}{l}(0-0)^{2}+(1-0)^{2}+(1-1)^{2}+(1-1)^{2}+ \\
(1-1)^{2}+(1-0)^{2}+(0-0)^{2}+(0-0)^{2}+ \\
(0-1)^{2}+(1-0)^{2}+(1-1)^{2}+(1-0)^{2}+ \\
(1-1)^{2}+(0-0)^{2}+(0-0)^{2}+(1-1)^{2}+ \\
(0-1)^{2}+(1-0)^{2}+(1-1)^{2}+(1-1)^{2}+ \\
(0-0)^{2}+(0-0)^{2}+(1-1)^{2}+(1-1)^{2}+ \\
(0-1)^{2}+(1-1)^{2}+(1-1)^{2}+(0-0)^{2}+ \\
(0-1)^{2}+(1-1)^{2}+(1-1)^{2}+(1-0)^{2}+ \\
(0-1)^{2}+(1-1)^{2}+(0-0)^{2}+(0-0)^{2}+ \\
(1-1)^{2}+(1-1)^{2}+(1-1)^{2}+(1-1)^{2}+ \\
(0-1)^{2}+(0-0)^{2}=12\end{array}$ \\
\hline $\mathrm{M}$ & $\begin{array}{l}(0-0)^{2}+(0-0)^{2}+(1-1)^{2}+(1-1)^{2}+ \\
(1-1)^{2}+(0-0)^{2}+(0-0)^{2}+(0-0)^{2}+ \\
(1-1)^{2}+(0-0)^{2}+(1-1)^{2}+(0-0)^{2}+ \\
(1-1)^{2}+(0-0)^{2}+(0-0)^{2}+(1-1)^{2}+ \\
(1-1)^{2}+(0-0)^{2}+(1-1)^{2}+(1-1)^{2}+ \\
(0-0)^{2}+(0-0)^{2}+(1-1)^{2}+(1-1)^{2}+ \\
(1-1)^{2}+(1-1)^{2}+(1-1)^{2}+(0-0)^{2}+ \\
(0-0)^{2}+(1-1)^{2}+(1-1)^{2}+(1-1)^{2}+ \\
(1-1)^{2}+(1-1)^{2}+(0-0)^{2}+(0-0)^{2}+ \\
(1-1)^{2}+(1-1)^{2}+(1-1)^{2}+(1-1)^{2}+ \\
(1-1)^{2}+(0-0)^{2}=0\end{array}$ \\
\hline $\mathrm{Z}$ & $\begin{array}{l}(0-0)^{2}+(0-0)^{2}+(0-1)^{2}+(0-1)^{2}+ \\
(0-1)^{2}+(0-0)^{2}+(0-0)^{2}+(1-0)^{2}+ \\
(1-1)^{2}+(1-0)^{2}+(1-1)^{2}+(1-0)^{2}+ \\
(0-1)^{2}+(0-0)^{2}+(1-0)^{2}+(1-1)^{2}+ \\
(1-1)^{2}+(1-0)^{2}+(0-1)^{2}+(1-1)^{2}+ \\
(1-0)^{2}+(1-0)^{2}+(1-1)^{2}+(1-1)^{2}+ \\
(0-1)^{2}+(1-1)^{2}+(1-1)^{2}+(1-0)^{2}+ \\
(1-0)^{2}+(0-1)^{2}+(0-1)^{2}+(1-1)^{2}+ \\
(1-1)^{2}+(1-1)^{2}+(1-0)^{2}+(0-0)^{2}+ \\
(0-1)^{2}+(0-1)^{2}+(0-1)^{2}+(0-1)^{2}+ \\
(0-1)^{2}+(0-0)^{2}=23\end{array}$ \\
\hline
\end{tabular}


Dari perhitungan yang dilkaukan didapatkan bahwa nilai yang terkecil yaitu 0 , nilai error 0 tersebut yaitu karakter 'M'. Sedangkan karakter lain yang memiliki nilai terkecil berikutnya yaitu 12 dengan karakter huruf 'N'. Dengan demikian dapat dilihat bahwa dengan menggunakan algoritma template matching, komputer dapat mengenali huruf didalam citra digital dengan baik.

\section{Kesimpulan}

Dari penelitian yang dilakukan dapat disimpulkan beberapa hal sebagai berikut:

1. Algoritma template matching memiliki kelebihan dari segi penerapan algoritma yang sederhana, sehingga pemrogram dapat dengan mudah membuat aplikasi pengenalan huruf menggunalan algoritma ini.

2. Algoritma template matching membutuhkan penyimpanan yang cukup besar untuk menyimpan data pengetahuan yang akan dibandingkan dengan data input, semakin banyak data yang terdapat didalam database maka akan semakin akurat data yang akan dikenali menggunakan algoritma template matching.

\section{Refrences}

[1] Made Sulatri Dewi, Made Windu Antara Kesiman, I Made Gede Sunarya. "Aplikasi Pembelajaran Pengenalan Aksara Bali Menggunakan Metode Template Matching". JANAPTI Vol. 3 No. 1. 2014.

[2] Ni Kadek Ayu Wirdiani. "Pembentukan Pola Khusus Untuk Ekstraksi Ciri Pada Sistem Pengenalan Aksara Bali Cetak". Universitas Udayana Denpasar. 2011.

[3] Rendra Pranadipa, Vika Novitasari, Maya Kurniawati, Nurlia Puspitasari, Yana Bonita. "Pengenalan Angka Pada Plat Nomor Dengan Metode Template Matching". Universitas Brawijaya. 2013.

[4] Rezki Trianto, Ni Nengah Dewi Merdekawati, Rizkie Purnama Shakti Nugraha, Dita Nur Yuni Astiti, Happy Gagas Tri Atmojo. "Klasifikasi Huruf Katakana Dengan Metode Template Matching Correlation". Universitas Brawijaya. 2013.

[5] Suryo Hartanto, Aris Sugiharto, Sukmawati Nur Endah. "Optical Character Recognition Menggunakan Algoritma Template Matching Correlation". JOINT Vol. 1 No.1. 2012. 